\title{
Discerning a theological agenda for spatial justice in South Africa: An imperative for sustained reconciliation
}

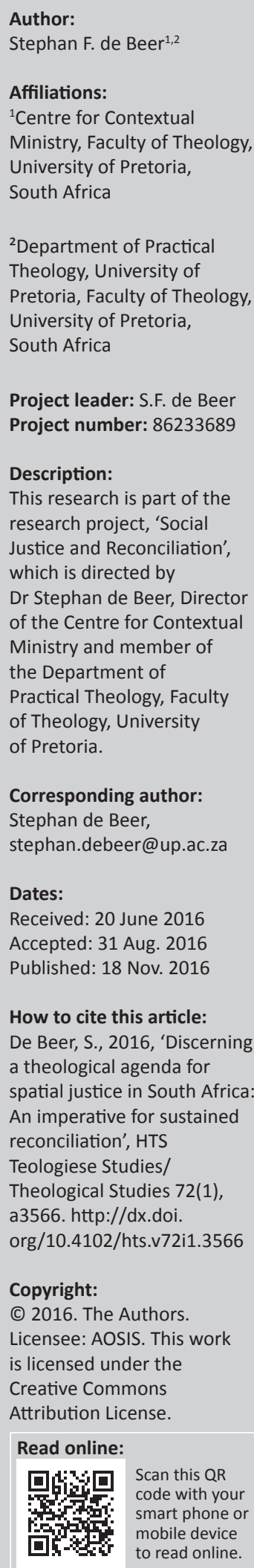

A spatial turn has occurred in various disciplines over the past decades. This article holds that it has not occurred in a similar decisive manner in theological discourse and not in South Africa in particular. After considering the necessity of a spatial turn and spatial consciousness, the article examines the concept of spatial justice against the backdrop of how injustice was and is spatially expressed in South African cities. Considering the way in which South African cities have evolved since the Native Land Act of 1913 - the segregated and apartheid city and the (post)apartheid city the article then argues that deep and sustained reconciliation will be impossible should current spatial patterns of segregation, exclusion and injustice continue. It advocates theological and ecclesial participation in a national agenda for spatial transformation, to be fleshed out in relation to four interconnected challenges: land, landlessness, housing and home; the 'creative destruction' of neighbourhoods, gentrification and the displacement of the poor; participation in city-making (from below) and transformative spatial interventions; and close collaboration with social movements working for spatial justice. It concludes by asserting that such a trans- and/or postdisciplinary agenda for spatial justice would participate with the Spirit to mend the oikos of God.

\section{Spatiality, (in)justice and reconciliation: The challenge}

A student in a recent class observed, with despondency: 'Things have not changed; they merely shifted'. He was referring to a city-wide mobile classroom during which we visited different urban neighbourhoods, specifically looking at issues of social and spatial mobility, integration or segregation, and (in)equality.

It is indeed a question of great concern: why have our cities, to a large extent, often remained as spatially divided as pre-1994? Where they seem to have changed, the deeper reality simply seems like shifts that have taken place instead of deep transformation; why is the lack of spatial transformation lamented in national policy documents, yet local government programmes and even national housing delivery continue to perpetuate apartheid spatial patterns? What is the theological imperative in a context such as this, if any?

The questions underlying this special collection of articles, as well as my own article, are threefold:

- To what extent should reconciliation be made visible through an increasing sense of spatial justice? Or is one of the signs of shallow or unsustainable reconciliation the evidence of continuous spatial segregation or the spatiality of injustices?

- Alternatively, can an increasing sense of spatial justice, or justice being spatially embodied, assist in the work of deep and sustainable reconciliation?

- How do we discern a theological agenda for spatial justice (and reconciliation)?

- Does a theological agenda for spatial justice and the very notion of spatiality as a vital category for theological consideration not require a spatial turn or spatial consciousness, as has been the case with a number of other disciplines?

The essence of what this article explores is an articulated theological agenda for spatial justice as both a prerequisite and an imperative for deep, authentic and sustained reconciliation.

\section{The spatial turn and spatial consciousness}

\section{The spatial turn}

It was in the more 'obvious' disciplines of urban planning, architecture and geography that the so-called spatial turn first took place over the past decades. Since then other disciplines have

Note: This article is part of the Special Collection titled 'Spatial Justice and Reconciliation', sub-edited by Stephan de Beer, of the Department of Practical Theology and the Centre for Contextual Ministry, University of Pretoria.

This article emanates from a joint consultation on Spatial Justice and Reconciliation, co-hosted by the Centre for Contextual Ministry, Faculty of Theology, University of Pretoria, South Africa. 
also started to develop critical spatial thinking, ranging from social work and development studies to legal philosophy and theology (cf. Soja 2010:13-14). The spatial turn constitutes critical spatial reflection, de-neutralising spatiality, recognising the socio-political nature of spatial construction, and 'beginning to reverse a century and a half of relative neglect of spatial thinking' (Soja 2010:14).

Soja (2010) says:

Perhaps never before has the spatial organisation of human society, particularly as it takes shape in the modern metropolis and the expansive global economy, been as widely recognised as an influential force shaping human behaviour, political action, and social development. (p. 14)

However, it remains to be seen whether the spatial turn has indeed been made in theological discourse. When I use the term 'spatial turn', I mean it the sense of critical spatial theory as embodied by Henri Lefebvre $(1974,1996)$, David Harvey (1978, 2000, 2012), Edward Soja (2010) and others, deconstructing the kind of spatiality that is currently often perceived to be a 'neutral backdrop' to our lives.

We should take our cue from people like Tim Gorringe, Sigurd Bergmann and Gert Prinsloo, who are paving the way for critical spatial thinking in theological or biblical terms. Prinsloo (2005, 2013, 2014, 2015), a scholar of Hebrew and ancient languages, considers Hebrew and other ancient Mediterranean texts through the lenses of critical spatiality. He retrieves and engages the thought of critical scholars such as French Marxist Henri Lefebvre and geographer Edward Soja in spatially reading, for example, Psalm 11. Prinsloo (2015) argues that:

[S]patial concepts lie at the heart of suffering human beings' struggle to construct meaning. Taking cognisance of a text's spatial dimensions can aid us in understanding the psalmists' struggle to construct meaning in the disjunction and discordance brought about by suffering. (p. 778)

In reflecting on Psalm 13, Prinsloo (2013:774) takes it even further, speaking of suffering as 'an intimate, personal intense experience, experienced $b y$, and quite often, in the suffering body'. Suffering, he holds, is often not merely a spatial but an intensely bodily experience, giving shape to space through 'acts of spacing' and the 'constant process of shaping space and being shaped by space'.

Perhaps one of the clearest pieces considering 'theology in its spatial turn' is an article by Sigurd Bergmann, published in 2007, entitled 'Theology in its spatial turn: Space, place and built environments challenging and changing the images of God'. Bergmann writes as if a spatial turn has indeed occurred, outlining historical evolvement of spatial language and discourse in theology, even if not labelling it as such. Some of what Bergmann refers to indeed draws deeply from critical spatial theory, but often the spatial discourses Bergmann refers to tend to be rather acontextual, void of an actual locale.
Bergmann (2007:359) himself focuses his spatial thinking in the sphere of 'a synthesis of ethics and aesthetics' well captured in his anthology Architecture Aesth/Ethics and Religion (2005), in which he draws richly from architecture, the arts, ecological theology and urban planning. Bergmann (2007:359) considers as a contextual theological challenge to deliberately move 'into the spaces and places where God's Holy Spirit redeems the creatures and creation'. He then asks what could be a core question in a spirituality taking spatial constructions seriously: 'Where do we find the habitats of the life-giving Spirit?' (Bergmann 2007:359).

In reflecting on what he considers a 'spatial turn' in theology, Bergmann (2007:356-357) starts off by retrieving works of Moltmann. In God in Creation (1985), Moltmann focuses on ecological matters from a theological perspective with a specific section about 'the space of creation'. In a later publication, Moltmann (2002) concerns himself with the 'living spaces of God', in other words 'the question of how God dwells in space and time' (Bergmann 2007:356). Moltmann's contribution is crucial for a language that understands God 'as a God with and within space' (Bergmann 2007:356). If that is embraced as a theological notion, how God is in contested spaces, where the flow of capital and the suffering of the poor in God's image often clash, needs then to be interrogated. Does God indeed show up within space in the cries of the suffering and excluded poor?

For that I will turn to another scholar retrieved by Bergmann (2007:355): a Lutheran Cherokee, or Cherokee Lutheran, George Tinker. Tinker (1994) insists on locating a vision of liberation in concrete space and place, emphasising the postcolonial quest for a reconstruction of indigenous spiritualities and human ecological practices in natural and nowadays late modern surroundings' (Bergmann 2007:355). The urge of this article would be similar in its call for a spatial justice agenda, concretised in local space and place, where liberation needs to be worked out concretely in deliberate, creative or subversive resistance to death-dealing forces.

Unlike Moltmann's emphasis on space, John Inge focuses on 'place' as concretisation of space (Inge 2003), considering alternative imaginaries that would protest what he laments as the dehumanising loss of place. He insists that Western theology in particular has not taken place seriously as category of theological reflection.

Kjellberg (2000) is a Finnish theologian and ethicist who constructed a vision of 'the ecological city of the future', proposing 'deep cosmological holism' against 'shallow anthropocentric sustainability' (cf. Bergmann 2007:358). His is a particularly valuable contribution to rethink urban planning from an ethical and ecotheological perspective. Anne Primavesi (2000), a British ecofeminist theologian, 'focuses on the Earth as a common space for living' (Bergmann 2007:362), rooted in ecospiritualities that maintain the integral connectedness of all of nature, including humanity, to the Earth. 
Other important spatial contributions mapped by Bergmann include land discourses by biblical scholars such as Brueggemann (1977) as well as scholars investigating new religiosities and how they are embodied spatially and in place (Ivakhiv 2001).

Bergmann (2007:358-359) devotes a section of his article to the important work by British theologian Tim Gorringe. In a Theology of the Built Environment, Gorringe (2002) laid a solid theological foundation to be built upon for spatial theological discourse, but again not enough has been done theologically or ecclesially to translate Gorringe's work contextually and concretely into contested spaces or places. Gorringe, drawing on a range of sources from various disciplines, places redemption at the centre of his theology:

Gorringe develops a strong ethical commitment and discussion of justice in the contexts of ownership of land, housing, and the demand to an environmentally sustainable mode of housing for 6 billion inhabitants on Earth. (Bergmann 2007:359)

Although Gorringe does not speak of it as a spatial turn, Bergmann (2007:359) thinks of Gorringe's contribution 'as a breakthrough for theology in general' but in particular for spatial theological discourse. Gorringe also contributes in a unique way theologically 'to the broader discourse on built environments'.

Gorringe (2002) writes poetically about this challenge:

To be human is to be placed: to be born in this house, hospital, stable (according to Luke), or even, as in the floods in Mozambique in 2000, in a tree. It is to live in this council house, semi-detached, tower block, farmhouse, mansion. It is to go to school through these streets or lanes, to play in this alley, park, garden; to ship in this market, that mall; to work in this factory, mine, office, farm. These facts are banal, but they form the fabric of our everyday lives, structuring our memories, determining our attitudes. How, as Christians, should we think of them? Are they a proper subject for theological reflection? (n.p)

Although Bergmann eloquently and rather comprehensively maps what he thinks of as theological reflections with a spatial focus, I suggest that the spatial turn still needs to be made more 'obvious' theologically, specifically in the South African (urban) context. It has not yet been made obvious, perhaps often because of theological engagement that is detached from radical discipleship, the suburbanisation of theology (in most mainstream theological schools in South Africa), the entanglement of mainstream Christianity with social and economic constructs that mediate socio-economic exclusions (a Constantine form of Christianity in which political power, financial capital and religious form collude) and the lack of deep contextual engagement in constructing theological language and responses in South Africa today.

\section{Spatial consciousness}

I argue here that a spatial consciousness (cf. Soja 2010:17-20) needs to be very intentionally fostered theologically and in local faith communities: for people to see, understand and interpret spatiality; to dissect the myth of spatial neutrality; to understand how spaces and places are constructed socially, economically and politically; to understand the spatiality of injustice and corresponding socio-economic exclusions; the way in which a certain understanding and working of capital ensure spatial inequalities; the relationships between land, space, place and housing or 'home'; the complicity of the church in co-constructing spatial injustice or the possibility of the church to mediate justice spatially; and developing critical spatial perspectives, theologically, about all of these categories.

Spatiality indeed deals with all of life, just as theology, and therefore needs our fullest and best attention. Soja (2010:17) speaks of the 'spatiality of human life' as 'a complex social product, a collectively created and purposeful configuration and socialisation of space that defines our contextual habitat, the human and humanised geography in which we all live our lives'. Spatial injustice results not in humanised geography but in dehumanised (non)places disconnected from life, opportunity and urban resources.

Soja (2010:18) continues to say that 'human life is ... spatial, temporal, and social, simultaneously and interactively real and imagined'. Although human life is all of that, is it indeed simultaneously good, free and flourishing? Fostering a spatial consciousness theologically would engage deeply with 'real' spaces and places but also collaborate with 'real' people to imagine alternative possibilities that would dismantle dehumanised (non)places and replace them with just and flourishing places.

The starting point in fostering a spatial consciousness is to firmly assert that space, spatiality and spatial formation are not neutral but determined; constructs and constructed; real and imagined; perceived and experienced; colonial, postcolonial, neocolonial; life-giving or violently dealing death. Spatial consciousnesses reflect on spatiality in nuanced and differentiated ways, helping local faith communities and faith-based social movements to make sense of spatial realities; considering how ethics and aesthetics could collaborate in reimagining and transforming spaces physically, socially, politically and psychologically; and to become agents working for spatial justice whilst deliberately resisting forces that shape spatial injustice.

\section{Spatial justice and the spatiality of (in)justice in South African cities On spatial (in)justice}

Soja (2010:5), in Seeking Spatial Justice, emphasises how, until the late 20th century, spatial justice as a phrase had hardly been used, as is evident from less than a handful of scholarly publications using the phrase at all. Soja (2010:5) indicates how other terms were used when referring to the spatiality of justice - 'the urbanisation of injustice', 'the geography of social justice', 'environmental justice' or 'territorial justice'. One gathers, even from the theological mapping of spatial 
discourse as carried out by Bergmann, that spatial justice as a phrase was not used by any of the theologians he retrieved, at least not by 2007 .

Referring to Edward Said, Soja (2010:1-2) holds that the practice of seeking spatial justice is a 'struggle over geography' and 'a vital political objective' (Soja 2010:20). It asserts that the spatial structure as we have it is not a neutral, accidental background to urban life but politically and socially shaped, often rather deliberately, including some and excluding others. The spatial focus of justice does not imply that other forms of justice - social, political, economic or environmental are now less important. It rather seeks to correct the negation of the spatial as if it was simply a backdrop to other forms of contestation. The spatiality of (in)justice needs to be understood in close conjunction with the urbanisation of (in)justice. This is not restricted to local urban processes only, but the global city and corresponding processes of global capitalism now also usurp rural areas, suburbs and unspoiled green areas (cf. Merrifield \& Swyngedouw 1995; Soja 2010:6).

Spatial justice, therefore, is socio-economic-political (in)justice spatially expressed. It was Lefebvre in Paris who started to express a concern with the ways in which cities were constructed to exclude migrant communities. The colonial and postcolonial city was clearly constructed to mediate racial, ethnic and economic segregations. The IsraeliPalestinian contest is playing itself out spatially (cf. Soja 2010:40-42), with the occupation of Palestinian territory signifying socio-spatial control not only in a physical sense but also in a psychological and spiritual sense. Bulldozers, tunnels and militarised walls become the dominant images for building and sustaining segregated and unjust geographies, not only in Palestine but also in both apartheid and, tragically, (post)apartheid South Africa.

\section{From apartheid to (post)apartheid cities}

In South Africa the apartheid city took socio-spatial control to its most extreme form in legislated segregation, restricting the movement and access of black South Africans to urban areas, thereby denying them citizenship in their own country. Even before the apartheid state came to power, the Native Land Act of 1913 (South African History Online [SAHO] 2015) dictated spatial arrangements across racial lines, excluding the vast majority of the population from equal spatial participation and cohabitation. The segregated city that resulted was institutionalised in the formation of the apartheid city structure with separate neighbourhoods assigned for different racial groups, often arbitrarily and unscientifically defined. Black South Africans were not able to move freely in neighbourhoods assigned to white people only, having to carry a pass, without which they risked arrest after a certain hour of the day. White neighbourhoods were centrally located places of privilege, with easy access to quality urban services, resources and opportunity, unlike the neighbourhoods that became known as 'urban townships'. Urban townships were the places where black, Indian and so-called coloured South Africans were forced to live.

\section{Urban townships and informal settlements}

With the fall of apartheid and apartheid legislation such as the Group Areas and Influx Control Acts, black urbanisation intensified and gave rise to mushrooming urban informal settlements, now spanning the national landscape in every region. Vellem (2014:207) describes more than 2000 informal settlements in South Africa and 182 such settlements in Johannesburg alone (in reference to Anton Harber). The Integrated Urban Development Framework (2014:31) describes this reality and related 'infrastructure backlogs, as well as more marginal and un-serviced settlement areas' as a primary challenge in building integrated and sustainable human settlements. Simultaneously this becomes a huge environmental challenge, from the perspectives of both urban sprawl and also associated pressures of 'sufficient water supply, urban waste management, air and water pollution, degradation of vulnerable eco-systems and the erosion of arable land' (Integrated Urban Development Framework 2014:31).

Despite their violent origins, urban townships cannot simply be torn down. The Integrated Urban Development Framework (2014:33) therefore envisages as one of its priority areas the redevelopment of townships through investment in public infrastructure, strengthened transport links between townships and hubs of economic opportunity, and improved public health and education infrastructure. The ways in which informal settlement upgrading, township reinvestment programmes and linkages between formerly and new marginal areas in urban centres of power and capital are forged, or neglected, will be expressions of spatial (in)justice.

\section{Inner-city (dis)investments and suburban explosions}

Inner city areas in South Africa are unique in how they have evolved since the early 1990s. With political changes, an exodus of white capital and white institutions from inner cities occurred - what some speak of as 'locational discrimination' - and often this was followed by the disinvestment of banks and collapsing neighbourhoods. These then became the first neighbourhoods of access for both the black middle and working classes and poor black people looking for economic opportunity and since the 2000s have become home to many Africans from across South Africa's borders, making the inner cities into truly panAfrican neighbourhoods. Social and inclusionary housing models were often pioneered in inner city areas, prophetically undoing the apartheid city structure and demonstrating the possibility of new forms of diversity coexisting in local neighbourhoods. This has led the Integrated Urban Development Framework (2014:32) to prioritise the regeneration of inner cities because of their strategic position as 'arrival areas' and places of strategic access to employment, education, housing and other services.

Since the 1990s there has often been a direct correlation between disinvestment from inner cities and suburban 
explosions around shopping malls. Areas such as Brooklyn, Menlyn and Centurion in Pretoria/Tshwane are appropriate examples. Twenty-two years later, pockets of the inner city in Pretoria and Johannesburg are starting to become attractive to investors again, once again however threatening poorer populations residing in these areas because investment tends to push up property prices and push out the poor. I understand these processes best by way of Harvey's description (1978) of how capital operates:

Under capitalism, there is a perpetual struggle in which capital builds a physical landscape appropriate to its own condition at a particular moment in time, only to have to destroy it, usually in the course of crises, at a subsequent time. This temporal and geographical ebb and flow of investment in the built environment can be understood only in terms of such a process. (p. 124)

The urbanisation or spatialisation of injustice is practised in the ways and directions in which capital flows.

\section{Urban-rural divide}

Similar processes are evident in the urban-rural divide. In The Production of Space, Lefebvre (1974) described the way in which the rural became consumed into the city through extracting labour without investing back, through privatising natural spaces as weekend getaway zones and through urban sprawl slowly absorbing green spaces into the urban mass (cf. also Harvey 2012:xv). Perkinson (2001) speaks of the city as having a large, consuming mouth, absorbing what it chooses to and discarding the rest. The Integrated Urban Development Framework (2014:38) therefore makes it a clear priority to consider the development of strategic infrastructure to bridge the urban-rural divide, providing 'access to urban markets, health and education facilities, and employment opportunities, thereby enhancing socioeconomic development'.

\section{Intensified spatial contestations}

In postapartheid cities the contestation over space is becoming more intensified as the years go by. Hendricks and Pithouse (2013:104) state that 'it was simply assumed that the defeat of apartheid would automatically resolve the urban question' and with it urban spatial and land relationships. However, in a real sense one can at best speak of the (post) apartheid city in a way that recognises how little has changed spatially. Hendricks and Pithouse (2013) illustrate this point:

\footnotetext{
... both the apartheid state and private power have actively and often effectively sought to continue exclusionary spatial practices in the democratic era ... In fact, in important respects, there have been strong continuities in certain state practices, including violent ones, during and after apartheid. (p. 104)
}

Spatial contestations manifest in different ways post-apartheid. In the absence of apartheid legislation, the technocratic clarity of who has a right to the city and who does not has fallen away. It is clear how political will (and the lack thereof), private capital and often the collusion of political power and capital are mostly determining urban spatial arrangements.

\section{'Security-obsessed urbanism' and revolt from below}

The spatial and territorial gains made in this way since 1994 are maintained through what Soja (2010:42) speaks of as 'security-obsessed urbanism'. This is evident in private households, in city centre surveillance and militarisation, but most notably in the mushrooming of gated communities, 'a fortressed housing compound often protected by armed guards and various visible and invisible indications that trespassers will be shot' (Soja 2010:43). Gated communities and the privatisation of public spaces such as parks seek to control access to the city, urban resources and participation in processes of city-making, deliberately excluding some, mostly if they do not express the 'right' racial, ethnic or economic profile.

Soja (2010:43) speaks of this as the dilemma of spatial injustice on the one hand and 'extreme expressions of democratic individualism and freedom of choice' on the other. It marks a departure from civic engagement with the public or 'the other', instead opting for 'privatopias' (McKenzie 1994), 'spatial colonisation' (Soja 2010:43) or 'the urbanisation of injustice' (Merrifield \& Swyngedouw 1995; Soja 2010:49).

And yet, from below, there is growing revolt against what some call a 'white city', a 'neoliberal city' or a 'city of capital'. One sees this in widespread protest actions, well-organised or spontaneous land occupations, and intersectional decolonisation movements. It also becomes evident in the suburbanisation of homelessness in South African cities and towns (cf. De Beer \& Vally 2015:63-65). In the past, street homelessness was mostly constricted to the central areas of cities. Today in the city of Tshwane, $44 \%$ of street homeless people live in parks, on pavements, in bushes or under bridges, in more resourceful suburbs, close to shopping malls, construction sites and economic hubs. This is not an organised movement but a spontaneous, economically driven 'infiltration' of suburbia from below. With time and organisation between clusters of street homeless people across the city, collaborating with other social or landless movements, this could become a political infiltration reshaping the urban landscape considerably.

Hendricks and Pithouse (2013:105) show how the academy has been extremely slow to engage such urban spatial contestations that have intensified from below. The reasons they suggest for such slow engagement include the 'reduction of the land question to a rural or agrarian question'; not regarding the urban poor as political subjects - therefore simply not taking them seriously; 'the subordination of academic work to donor and state agendas'; reducing the urban spatial or land question to housing and then the quantities of housing delivered; or reducing popular dissent to 'a demand for service delivery'. What they highlight is how all such reductionist approaches negate the vital political question of how cities are governed and land allocated. It is indeed the question of who has a right to the city - a struggle over geography. 


\section{Spatial (in)justice and reconciliation}

A central question of this article is whether deep and sustained reconciliation is possible without spatial justice. The answer depends on one's definition of 'reconciliation'. Some theorists might consider reconciliation in a 'softer' sense with an emphasis on restored relationships, emotional and psychological healing, and giving and receiving forgiveness, without necessarily considering the 'harder' issues of restitution, redistribution or justice. Reconciliation in that sense resides in the personal and interpersonal spheres. However, others would locate reconciliation in a broader socio-economicpolitical context, arguing that authentic reconciliation is impossible without achieving greater degrees of social justice.

In this article I depart from an understanding that reconciliation and justice can never be mutually exclusive for reconciliation to be authentic; that the one does not really exist without the other except in its pretention of authenticity; and that the spatiality of (in)justice needs to be engaged theologically in a much more comprehensive, careful and strategic manner, if theological engagement is to contribute to the mending of the oikos, here meant specifically in and for the South African context, yet within an understanding that it is globally embedded.

Nelson Mandela (1995) understood reconciliation as 'working together to correct the legacy of past injustice'. For him reconciliation implied substantive measures to address structural and socio-spatial injustices (even if he did not use the exact same language). In a similar way the Restitution Foundation (2016) works for socio-economic justice, healing and reconciliation through restitution. They envisage authentic and sustained healing and reconciliation, as well as socioeconomic justice, through acts and processes of restitution that would engage measures to correct past and present wrongs. To them therefore, in my reading, restitution is the means to mediate reconciliation-justice, or reconciliation with justice, or just reconciliation.

Sampie Terreblanche, from a political economic perspective, argued several times and on different occasions that South Africa's Truth and Reconciliation Commission should have been followed up with a Justice and Reconciliation Commission, in order to address more substantively matters of socio-spatial-economic injustices, the return of land and spatial transformation. In an article in the Mail $\mathcal{E}$ Guardian newspaper, Terreblanche (2012) wrote:

In the South African case, both rich whites and rich blacks are guilty of the self-attribution fallacy. Perhaps we need a justice and reconciliation commission to examine power relations over the past 120 years to infuse the necessary degree of humility among both the old white elite and the new black elite. It is important that the rich in South Africa should be informed about the central role that skewed political and corporate power played in creating their opulence. (n.p)

It was much earlier though, in 1997, that Terreblanche and Mahmood Mamdani first called for such a commission to develop a comprehensive programme of 'restitutional equality ... to counteract the devastating reality of 354 years of racialised capitalism' (cf. Cornell 2014:73). Then, in a joint article in the Cape Times, Cornell, Mamdani and Terreblanche (2008) called for such a commission again, in no uncertain terms arguing the importance and reasons for their call. They start by referring to the widespread violence that was sweeping the country in 2008, aimed at vulnerable foreign nationals:

We believe that the violence that South Africa has experienced over the last week is systemic in nature and will not end until the underlying causes of economic distress have been dealt with thoroughly.

South Africa is in a state of emergency because of the failure to address desperate poverty and is in urgent need of a mechanism to begin public discussion on how to ensure dignity for all those who live here. (n.p)

They continue to speak about poverty, especially as experienced in black townships, and how the 'unbearable living conditions' led to 'the current outpouring of frustration and rage in various South African townships' (Cornell et al. 2008).

They propose that there is only one solution, 'which is to address the underlying economic distress - to address the complete failure of supply-side capitalist economics in South Africa'. In order to start to address that they consequently proposed a Justice and Reconciliation Commission:

The aim of such a commission is to focus on the systematic character of racial capitalism, which began long before the institutionalisation of apartheid.

The work of such a commission would be both to educate whites, who were the beneficiaries of this exploitative system, as well as to develop a programme of reparations, restitution and, perhaps most important, the establishment of economic measures that could effectively grapple with the devastating institutional effects of an internal system of colonisation.

We are calling for a 2-year commission to take up this work. The commission would also explore alternatives to the current Anglo-Americanisation of the South African economy, which has effectively blocked any substantive development of the country. (Cornell et al. 2008)

Very little attention was given to repeated calls for a Justice and Reconciliation Commission. And yet, they asserted:

As long as this extreme injustice continues to exist, we are naïve to have any expectation of peace.

Current spatial arrangements continue to perpetuate unjust cities, with access to power and opportunity still concentrating in the hands of a few at the expense of the majority of people. The way in which current state and capital power continues to perpetuate exclusionary spatial practices (Hendricks \& Pithouse 2013:104) does little for healing and reconciliation but rather fosters a deep sense of anger, frustration and embitterment, evident in growing occurrences of revolt that at some point will no longer succumb to security or military suppression by the state.

If that is indeed the case, as this article also argues, then the spatialisation of (racialised) capitalism, the urbanisation of 
socio-economic injustice, and any theological or ecclesial complicity in sanctioning, defending or reinforcing the status quo need to be theologically examined, unmasked and resisted with prophetic vigour. Without dismantling unjust socio-spatial constructs, 'we are naive to have any expectation of peace' or authentic, sustained reconciliation.

\section{A national agenda of spatial transformation: Bold priorities, bolder silences, local disconnects and the absence of the church}

One area in which theology, church and faith communities should engage more deliberately is with the national and local agenda for spatial transformation.

If human life is indeed spatial (Soja 2010:17-18) and if 'spatial concepts lie at the heart of suffering human beings' struggle to construct meaning', as Prinsloo maintains (2015:778), then theology that seeks to be life-giving needs to work itself out in the spatial realities and contestations of people and neighbourhoods where suffering and death are dealt routinely as the only options.

Chapter 8 of the National Development Plan (2012) focuses on the transformation of human settlements and is essentially a plan for spatial restructuring. This was further developed in the Integrated Urban Development Framework (2014), which outlines a vision, four goals and eight policy levers for transforming the South African urban landscape. The core thrust of this framework is to reverse the apartheid legacy of South Africa's cities and towns through comprehensive spatial restructuring, including strategic urban-rural linkages, seeking to overcome current and ongoing spatial and therefore also racial, social and economic - divides.

The bold priorities of the Integrated Urban Development Framework (2014) for reinvesting in urban townships, accelerating the upgrading and full integration of urban informal settlements, and making strategic infrastructure developments to bridge the urban-rural divide need to be lauded and implemented. The core driver of this framework is (rightly) spatial transformation of the South African landscape in the direction of greater socio-economic-spatial justice.

However, it is the (even bolder) silences of this framework that are of concern. The framework fails to deal with the current militarisation of local governments in the face of spontaneous revolts from angry and excluded urban inhabitants, often concealing poor management of informal settlement upgrading or land allocations. It fails to address land redistribution (except where land is owned by the state) in a decisive, visionary and clarifying manner. It fails to examine or critique the workings of capital in an honest and critical manner, as a vital challenge for spatial transformation - in spite of the fact that spatial formation is largely determined by the whims and flows of capital.
It is often in local municipalities, where the grandiose visions of national frameworks and policies need to be worked out concretely and carefully, that such visions unravel. The deep disconnects existing between national frameworks and local government practices are implied in some of what the Integrated Urban Development Framework (IUDF) describes as challenges, but these are not nearly adequately tackled. From a critical theological and spatial perspective, such disconnects need to be unmasked as unfortunate, sometimes even evil distortions or malpractices, depleting the commons; distorting national visions and destroying in very oppositional ways innovative alternatives to the status quo; and disturbingly arrogant in their marginalisation of the poor.

In the absence of bolder engagement with issues of militarisation of urban spaces, land redistribution, the workings of capital and corrupt collusion of state and capital, the chances of deep spatial transformation are slim. A critical theological assessment might go as far as suggesting that what is lacking is not merely honest analysis of some of the giants opposing spatial transformation, such as mentioned here, but that there is also a spiritual or moral deficit at the root of our spatial failures.

Should a theological agenda for spatial justice be embraced more fully, it would out of necessity have to start with critical self-reflection, acknowledging theological and ecclesial complicity in colonial constructs of power, capital and citymaking. This would include the way in which the church benefited unjustly from the 1913 Native Land Act without having done serious introspection or reflection on the possibility or imperative of engaging in acts of restitution, as well as current ways in which churches are stewards of land or property, but also how individual Christians contribute to spatial (in)justice through everyday practices. Circling wider than the church itself, a theological agenda for spatial justice would advocate spatial restructuring to more fully provide access to the city and urban resources to all of God's people. It should also seek to address the spiritual or moral deficit through fostering an alternative consciousness, instilling values of frugality and radical sharing, a reclamation of the commons through affirming our mutual interdependence, and a resistance of death-dealing forces such as greed, corruption and unbridled self-interest. It would demonstrate radical prophetic alternatives through lifestyle, ecclesial practices and innovative socio-economic transformations.

A theological agenda for spatial justice could contribute to the possibility of restored relationships - with self, others, the land and even with God. That would mean mediating deep and sustained reconciliation.

\section{A theological agenda for spatial justice: Considering, space, place and the built environment critically and constructively}

Currently there is no coherent spatial theological agenda to speak of in South African theological circles. Such an agenda 
would reflect theologically and critically on issues of space, land and the built environment, in conversation with other disciplines as well as movements from below, considering how social, political and economic power produce and reproduce space and how people and neighbourhoods are affected by socio-spatial processes.

There are disparate theological reflections on issues of land, the landless or the environment, but more should be done to foster a specific, collective and strategic theological agenda for spatial justice that will assume and facilitate a spatial turn and develop and articulate a spatial consciousness.

\section{Immersed in liminal spaces, in places of suffering and in critical spatial theory}

Such a spatial turn and spatial consciousness could hardly be developed in classrooms alone. It would require new, deliberate and deep-listening (not-knowing) immersions in liminal spaces and in places of suffering. At the same time it would require theology to engage with critical spatial theory in order to inform itself more adequately, developing the ability and consciousness to read spatial constructs and realities critically, with a view to deconstruct the often downright evil nature of spatial configurations.

As we work to foster a spatial turn and spatial consciousness, theologically and ecclesially, we also need to retrieve theological reflections on spatiality as developed by people like Bergmann, Prinsloo, Gorringe and others, as resources for spatial theological discourse.

A theological agenda for spatial justice will by definition be liberationist, playing itself out in local spaces and places (cf. Tinker 1994) - in liminal spaces between classroom and neighbourhood, between church and society, between powerful and powerless, between government and civil society - always assessing its city or town from the perspective of those most excluded or affected by spatial inequalities, spatial fragmentation or spatial marginalisation.

\section{Soul and spirituality of space and prophetic spatial embodiments}

Much has been written about the spirit of a space or place. To foster a spatial consciousness theologically, and to develop a theological agenda for spatial justice, would require collective discernment to identify what Norberg-Schulz (1980) calls the 'genius loci', or the spirit of a place. What is the dominant 'spirit', spirituality or ethos shaping spaces and socio-spatial relationships? In a city such as Cape Town, where evergrowing disparities are perpetuated between those living in informal settlements such as Khayelitsha - where many are still without access to water and sanitation - and those living in Bishop's Court or Clifton in properties valued from R25 million upward, what spirit could be hovering over that city?

The way in which a city is socially or spatially constructed tells a story of the city's spirituality. A greedy, profit-driven city will place much emphasis on monumental developments that often exclude the poor but testify to a certain kind of political and economic power. The gods of the market and capital have the upper hand and the church too often bows to the same gods. Can Christian theology, as part of a spatial justice agenda, discern where and how the Creator Spirit is hovering in resistance of death-dealing forces, seeking to liberate, redeem and transform in radically contrasting ways to what we have normalised as a society today?

Engaging the spirit of the city might have to happen at a theoretical level, but outwitting, unmasking and dismantling the spirit of the city might require innovative, critical and prophetic spatial embodiments, irruptions against the dominant narrative, boldly demonstrating with where we locate our bodies - the possibility of an alternative imagination. Whereas a theological agenda for spatial justice will depart from having made a spatial turn, in order to foster prophetic spatial embodiments it is essential to take note also of the corporeal, or bodily, turn (cf. Meiring 2014) in theology, which is deeply incarnational.

Spatial embodiments imply being physically located with our bodies - as churches, institutionally; as theologians or people of faith, individually. The question then becomes: where are we with our bodies? Our bodies exist in space and place. Meiring and Muller (2010) suggest that body theology can assist us to 'create a deeper awareness of our own embodiment, an awareness that we do not only have bodies but also are our bodies'. If we are our bodies, it means that our concrete embodiments alsoepistemologically mediate what and how we know. Our bodily locatedness - where we are incarnated - will mediate a certain kind of spatial consciousness that defies presumptions of neutrality. Just as we 'have bodies but also are our bodies' we also, as human beings, are spatial and in distinct ways we are our spaces.

In liberation theology 'the justice of God (is) unfolding through individuals' bodies and in the lives of the oppressed' (Punt 2005:371) and in feminist theory there is strong emphasis on 'the body as the site of experience'. Prophetic spatial embodiments will discern the yearning of the Spirit to mediate the justice of God as it is 'unfolding through individuals' bodies' and in the lives and death-dealing, excluded spaces of the oppressed. Elsewhere in this collection of articles, Jacob Meiring (in press) articulates it more clearly:

The argument is put forward that spatial justice is an embodied endeavour and that it cannot be achieved disconnected from the bodies of the persons in the concrete context where justice is strived for and where bodies can flourish. (n.p)

How could theological visions of justice and reconciliation therefore move beyond conceptual, philosophical or theoretical constructs and be concretely embodied institutionally, individually and theologically - by radically new socio-spatial structures, spatial immersions, incarnations and uses of land and property, mediating well-connected, well-integrated, fully flourishing bodies, people and places? 


\section{Socio-spatial strategies and tactics}

Whereas the spatial turn constitutes a conversion and spatial consciousness constitutes the process of creating a critical awareness and prophetic imagination for radically alternative spatial possibilities, theologians have the responsibility to explore and construct, in collaboration with faith communities, social movements and neighbourhood people, appropriate socio-spatial strategies that will translate a new spatial consciousness into 'transformative interventions' (Amin 2006). I speak of socio-spatial strategies here because of the important socio-spatial dialectic: social processes shape spaces and spatiality shapes social processes. The purpose of this article is not to devise sociospatial strategies but to provide some suggestions for a possible spatial justice agenda and to advocate for the necessity of developing prophetic socio-spatial strategies and tactics if we are to be faithful servants of God in specific, often highly contested localities.

I will restrict myself to proposing four specific areas for theological and ecclesial engagement, outlining perhaps an initial spatial justice agenda. In this regard I offer some broad-stroke thoughts on (1) land, landlessness, housing and home; (2) 'creative destruction', gentrification and the poor; (3) city-making (from below) and spatial transformation; and

(4) the church in collaboration with social movements.

\section{Land, landlessness, housing and home}

In a country where historically the Native Land Act of 1913 (SAHO 2015) effectively denied the vast majority of the population access to land or land ownership, safeguarding $93 \%$ of land for white ownership and allowing black ownership of only $7 \%$ of the land (later increased to $13.5 \%$ in 1936), contestations over land are obviously moving to centre stage in national and local politics. A theological agenda for spatial justice needs to engage issues of land and landlessness, but also corresponding issues of housing, home and homelessness.

The failure to move decisively on issues of land reform, land restitution or land redistribution results in spontaneous movements from below, occupying land in the absence of such access being granted. Such occupations are viewed as illegal invasions of land by officialdom or dominant discourses. From the perspective of those occupying land it is simply 'a fundamental affirmation of life' (cf. De Beer 2014; in reference to Gibson 2011:xvi; Lefebvre 1996:201, 1996:158), 'a cry for a new way of being human in the city, promoting the democratisation of the city from below' (De Beer 2014). It is at the same time a refusal to accept that a human being can be illegal when they find space in a city that does not offer them space. The prominent landless movement, Abahlali baseMjondolo, reflected on the issue of illegality in this way:

Our struggle and every real struggle is to put the human being at the centre of society, starting with the worst off. An action can be illegal. A person cannot be illegal, a person is a person wherever they may find themselves. (Gibson 2011:21)
In cities like Pretoria or Tshwane there is evidence of the suburbanisation of street homelessness as people spontaneously opt to make place for themselves in close proximity to real or perceived economic opportunity.

A theological agenda for spatial justice in South Africa will have to be much more reflective and constructive in proposing solutions to the ever-growing crisis of land, housing and spatial segregation. A 'head in the sand' approach will only postpone the inevitable, which already occurs sporadically in communities all over the country: revolt around access to and ownership of land and housing.

Only a few theological or faith-based institutions engage directly with issues of land. The Church Land Programme (CLP) (n.d) in Pietermaritzburg is probably a leading light in that regard. As part of their agenda they seek to transform theology through what they learn from grassroots struggles and their own attempts to develop a constructive land agenda. Transforming theology for them includes spaces in which people can articulate 'and make explicit their own theologies' (CLP n.d) but also spaces where the institutional church can make decisive shifts.

For many people, the institutional church is not present in their lives and suffering but appears rather as a servant of power. The 'people's church' (irrespective of denominational belonging) nevertheless remains very much part of their lives and CLP has created a variety of spaces for reflection through which people can explore and make explicit their own theologies.

At the same time, CLP remains cognisant of the social power of the institutional church and of the fact that it is not monolithic there are spaces where it can and does shift. It has seen the God of the powerful in the institutional churches confronted with the scarred and weeping face of God in the shack settlements and believes something true and powerful emerges from this confrontation.

The Ecumenical Service for Socio-Economic Transformation (ESSET n.d) is committed to theology and social justice, standing in solidarity with poor and vulnerable people and their socio-economic aspirations. They articulate their commitment as such:

Our interventions are aimed at fostering solidarity among churches with the social struggles of the poor and vulnerable social groups. (ESSET n.d)

Although they do not have a specific spatial agenda and their focus is not primarily on issues of land and housing, their commitment to socio-economic justice is playing itself out spatially and makes them an important collaborator in developing a theological agenda for spatial justice.

Grassroots faith-based movements such as the Warehouse in Cape Town (Warehouse n.d) and the Tshwane Leadership Foundation (TLF) in Pretoria or Tshwane (2016) have moved the justice agenda centre stage in the work they do. The Warehouse (n.d) is about 'serving the church in its response to poverty, injustice and division'. As one of its core objectives in 'working with churches and communities for urban 
transformation', the TLF is 'building inclusive and compassionate communities that practice justice and righteousness' (TLF 2016). Understanding their justice commitments spatially could perhaps be articulated even more deliberately, self-critically and constructively, but such movements also become important sites for constructing a theological agenda for spatial justice.

Faith-based housing companies such as Yeast City Housing (n.d) in Pretoria/Tshwane and Madulammoho (2010) in Johannesburg create well-managed and aesthetically pleasing social housing interventions in urban areas, creating access to urban centres for people ordinarily lacking access to welllocated affordable housing. Although they do not articulate it as such, the work of such faith-based housing organisations represents extremely important irruptions into the urban spatial fibre, demonstrating the possibility of inclusionary urban spaces and in small but significant ways reversing apartheid spatial patterns. In some cases they have helped to convert old church properties physically into multipurpose centres, creatively combining worship space with spaces for social services and social housing units.

In different cities networks are emerging, expressing deep concern over the reality of street homelessness. Local faithbased organisations or individuals of faith are often central to the organising of such networks, including the Tshwane Homelessness Forum (University of Pretoria 2015), the Street People's Forum (2016) in Cape Town and the work of the Dennis Hurley Centre (2012) in Durban. A theological agenda for spatial justice would see these spaces as sites of engagement, learning and reflection. Once such local networks get consolidated into a broader national conversation, not only considering practical interventions but discerning theological rationales and critique of current failures to address street homelessness, it can start to imagine innovative alternatives.

Theologians such as Koopman (2014), Resane (2015), Vellem (2014), Holtzhausen (2015), De Beer (2014), Van Schalkwyk (2014), Conradie (2006) and Mashau and Kritiznger (2014) consider issues of land, landlessness, homelessness or home as all reflections that are immensely spatial although not necessarily framed as such. Articulating a clearer spatial justice agenda theologically would require dialogue with and among these and other theologians, but also fostering collaboration with movements such as the CLP and ESSET, grassroots faith-based movements that are working for social justice, faith-based housing companies disturbing the status quo, other social movements working on issues of land or housing and, of course, most importantly the very people who suffer being landless, homeless or exposed to precarious housing themselves.

\section{'Creative destruction', gentrification and the poor: A theology of creative resistance}

Cities are made and remade. Capital is continuously looking for new places of absorption and consumption. Old or central urban neighbourhoods, in proximity to economic hubs, services and resources, are usually attractive for this purpose. If such new capital outlets require displacement of current tenants in the interest of the greater capital project, then profiteers and their political hosts have no scruples about implementing their plans. I briefly attend to processes of creative destruction, gentrification and the effects on the poor.

Harvey (2012) speaks of the way in which capitalist urbanism has shaped, structured and restructured cities, often steered not by grandiose visions of garden cities, such as that of Ebenezer Howard but in 'darker' ways through what he calls 'creative destruction':

This nearly always has a class dimension, since it is usually the poor, the underprivileged, and those marginalised from political power that suffer first and foremost from this process. Violence is required to achieve the new urban world on the wreckage of the old. (p. 16)

Haussmann's Paris (cf. Harvey 2012:16), built on the removal of the poor from central city areas, and the removal of 70000 poor people from neighbourhoods in Rio de Janeiro to make way for an Olympic Village, without being able to move back after this event because of the nature and cost of the new development, are cases in point.

Harvey (2012) speaks of Paris and how Haussmann:

created an urban form where it was believed ... sufficient levels of surveillance and military control were possible so as to ensure that revolutionary movements could easily be controlled by military power. (p. 16)

In the inner city of Pretoria two very visible examples exist. The Schubart Park apartment complex comprises four highrise buildings housing 700 families. ${ }^{1}$ After a combination of mismanagement by local government and non-payment of tenants, local government forcibly (the Constitutional Court later ruled illegally) evicted all the families in 2012. Instead of securing the buildings from vandalism, the buildings were completely stripped, becoming a place of no return.

Although the Constitutional Court ordered that the complex should be restored to continue offer social housing for people, the city's plans are for a multimillion-rand housing development catering for student accommodation and middle-income housing. The consortium that was formed and appointed to steer this development has failed to make it happen to date, but 700 families have already been left in the cold. This is a clear case of '(un)creative destruction' to make way for a more 'desirable' development.

Salvokop $^{2}$ is an inner-city neighbourhood in Pretoria in which the housing stock belongs to a national government department. The Department of Public Works has failed to

1.The process of Schubart Park has been well recorded by Van Marle and De Villiers (2013), Brand et al. (2013) and De Villiers (2014).

2.Also described by De Beer (2014), De Beer and Swarf (2014). 
manage their stock for more than a decade, allowing the slow destruction of the area through subletting, overcrowding, lack of waste removal and general mismanagement. What is expected is that all tenants will be evicted soon, to make space for developments that will be more lucrative financially, perhaps in the form of townhouse developments or a gated community. A R2 billion headquarters for Statistics South Africa and the Freedom Park Monument have already been erected in this neighbourhood. The significant capital investment, on the one hand, and the decaying residential sector, on the other, would not be tolerated into the future if capital had its way. And yet, the residential sector is deteriorating, rather deliberately it seems, as an act of creative destruction, under the (mis)management of a national government department.

Gentrification is the process whereby middle-class people start to move into depressed urban neighbourhoods, followed often by trendy restaurants and shops, pushing up property values superficially, leading to increased housing prices and the consequential displacement of the poor. It is often preceded by planned creative destruction, in the forms outlined above, to make space for gentrifying activities or simply through neglect and disinvestment by capital, until an area has depreciated far enough to make it attractive to capital once again, buying at low prices, inflating the prices, and forcing out the poor. In the South African situation, places like Woodstock and the Bo-Kaap in Cape Town are examples. Raymond Joseph (2014) reflects on the gentrification of Woodstock:

As developers increasingly buy up property, the poor yet tightly knit multi-racial community who once called this Cape Town area home are being driven apart by the rising cost of living. (n.p)

Sarah Jones, after living in Woodstock for 30 years, was evicted with her fellow tenants from a building that was renovated by its new owner, who then asked exuberant rents the tenants could no longer afford (Joseph 2014). She and other families sharing the same fate were forced out and now live in an informal settlement called Blikkiesdorp, 30 kilometres from Woodstock, and without access to similar socio-economic opportunity as they had in Woodstock.

Bo-Kaap in Cape Town is the traditional Malay Quarters, of great significance historically but also in terms of heritage value and its unique cultural identity. Kotze (2013) describes how in its case gentrification has had the same effect of increased property prices and corresponding hikes in rentals and property taxes, whilst at the same time 'community leaders and especially the Muslim residents are in a constant battle to preserve the neighbourhood's cultural identity'.

Capital is not respectful of the poor, cultural identity or heritage value. If not by the political force of bulldozers, it still bulldozes its way by other means. Gentrification is usually accompanied by displacement and dispossession. And displacement and dispossession are in almost all cases accompanied by surveillance and militarisation.
Just as inner-city decay and the suburban shopping mall are often two sides of the same coin, so are inner-city gentrification and urban displacement, the one having consumed the other, now leaving it to its own devices.

This is indeed a war on the poor, who are both structurally and physically removed and kept at bay. A theological agenda for spatial justice would have to consider strategies and tactics for engaging, with many others, in this war. It would need to ask difficult questions as to how to engage the violence of capital production, reproduction and exclusion, and its strategies and tactics would have to grow in intensity, sophistication and godly shrewdness if it is to outwit the Goliaths of this world. In response to capital's creative destruction, theological thought and actions should offer 'creative resistance'.

\section{City-making (from below) and spatial transformation}

A theology that integrates the 'right to the city' discourse into its own critical reflections will engage the city in a way that asserts its right (theology, church, faith-based movements) to participate in claiming 'some power over the processes of urbanisation, over the ways in which our cities are made and remade, and to do so in a fundamental and radical way' (Harvey 2012:5). It will facilitate a clear and critical shift in consciousness from being victims of urbanisation to being agents of resistance and subversion on the one hand, and constructors of radically alternative imaginations and possibilities on the other. It asserts a certain kind of agency, embracing citizenship, even if and where citizenship is effectively denied such as is the case in many urban informal settlements, refusing to be excluded on the basis of being equally human as all other inhabitants of the city.

The Isandla Institute (n.d) developed its thinking around the right to the city approach, among other things through hosting a dialogue series in 2011, exploring 'what the "right to the city" could look like in shaping an agenda for urban transformation in South Africa' (De Beer \& Swart 2014). They involved the urban poor as well as non-governmental organisations in this process (Görgens \& Van Donk 2012:6), eventually concluding that the right to the city in South African contexts would include 'the right to be in the city', 'the right to access city resources and opportunities', and 'the right to city-making' (Görgens \& Van Donk 2012:12-13).

To my mind the 'right to city-making' means an invitation to participate in city-making processes, including envisioning, planning, policymaking, budgeting process and actual project implementation on the ground. It also means asserting that right even if not invited, as citizens and inhabitants of the city and theologically as image-bearers of God. A theological agenda for spatial justice should participate in city-making processes, particularly from below and from within sites of contestation - informal settlements, gentrifying inner-city neighbourhoods, contested buildings, street homeless populations - because they are usually the uninvited guests at the tables of city-making. 
The theological work of academics, local churches and faithbased movements, in deep solidarity with those who are spatially excluded and marginalised, could contribute greatly to city-making from below, to give voice to suffering spaces, to articulate bold alternative imaginations and to contribute to spatial transformation.

Could local churches and schools of theology become sites of resistance, in solidarity with informal settlements and other at-risk places?

\section{The church in collaboration with social movements: Working for Jubilee irruptions}

It is often social movements emerging from the poor and in solidarity with the poor that are more prophetic than the church when it comes to issues of spatial justice. A theological agenda for spatial justice would have to consider collaboration in solidarity with social movements that articulate urban and other concerns clearly and that have often developed experience and competencies in engaging power strategically and tactically. The church's collaboration would clearly have to be as humble servant, learning from the struggles from below, of which it often knows very little.

And yet, having said that, the poor also resides in our churches, but the church's 'neutrality' and other-worldly theologies often prevent people from speaking about their socio-political-spatial struggles in the sacred space of worship. If the church only had ears to hear, it might hear not only the cries but also the aspirations and visions coming from within.

Harvey (2000) explores some of the social and political movements working for urban change from below in his book Rebel Cities. He and others speak of 'militant localism' when they describe local social movements that are committed to effecting change in areas ranging from gender and environmental injustices, to peace movements and cancelling international debt. Apart from well-articulated and often very sophisticated social movements for change, there are also what Soja (2010:34) speaks of as 'unarticulated justice movements'. In hundreds of cities and towns an escalation of protests is voicing anger and frustration about service delivery, landlessness or illegal evictions, giving clear expression to the effects of spatial injustice. These struggles often emerge from within 'forgotten' or 'invisible' spaces in the city, where the church too is absent. These, theologically speaking, could be regarded as:

$$
\begin{aligned}
& \text { spaces and places } \\
& \text { 'outside the city's gate' } \\
& \text { where Jesus met his fate }
\end{aligned}
$$

Harvey (2012:xvii) reflects on the necessity of so-called liminal social spaces as the locales for radical different imaginations and possibilities:

We do not have to wait upon the grand revolution to constitute such spaces. Lefebvre's theory of a revolutionary movement is the other way round: the spontaneous coming together in a moment of 'irruption', when disparate heterotopic groups suddenly see, if only for a fleeting moment, the possibilities of collective action to create something radically different. (Harvey 2012:xvii)

Social movements working for the right to the city or access to urban land can achieve small and even bigger victories. However, according to Harvey (2012:xviii), the 'capital system of perpetual accumulation along with its associated structures of exploitative class and state power, has to be overthrown and replaced'. He suggests that such exploitative practices can only be eradicated through a much 'broader revolutionary movement'. In the meantime, although the smaller movements collectively are vital as 'a way-station on the road to the goal. It can never be an end in itself ...'

Where churches participate with social movements to work for secure land tenure, to resist forced removals or to present alternative imaginaries of radically inclusive land development also integrating the poor, these all collectively become stepping stones towards dismantling the city that is.

An important and singular aim that Harvey (2012:22-25) identifies as a challenge for urban social movements is to gain 'greater democratic control over the production and use of the surplus'. In neoliberal cities the surplus gets privatised into the hands of small political and economic elites, and they determine who has a right to the city, or not. A strategic site of contest, for Harvey, would be:

$[T]$ o focus sharply on those moments of creative destruction where the economy of wealth-accumulation piggy-backs violently on the economy of dispossession, and there proclaim on behalf of the dispossessed their right to the city - their right to change the world, to change life, and to reinvent the city more after their heart's desire. (pp. 22-25)

Even the language of Harvey sounds evangelical: to proclaim to the dispossessed their right to the city, to life and to participation as image-bearers of God in making a city 'after their hearts' desire' sounds to me like good news to the poor, liberation to the oppressed, sight to the blind, the possibility of Jubilee irruptions into violent and violated places. A theological agenda for spatial justice would require broadbased collaborations between theology, church and social movements.

\section{A post- and transdisciplinary agenda: Mending the oikos of God}

Hendricks and Pithouse (2013) describe the informal settlement as 'a central site for popular protest':

And given that it is struggles over urban land that have generated some of the most acute conflicts between oppressed people and the state, we need to take struggles over urban land seriously. This requires careful theoretical work, rooted in sustained dayto-day immersion in the life worlds and struggles of the oppressed. (p. 126)

This in some ways provides the clues as to critical moments in a theological agenda for spatial justice: deep immersion in 
the life worlds of those who are spatially oppressed or excluded; collaboration with struggling people and settlements in solidarity, analysis, resistance, and protest; careful theoretical work to deconstruct current realities and foster an alternative spatial imagination; and collective actions, resisting death-dealing spatial practices and demonstrating possible alternatives.

The work of contextual and liberation theologians has all along been to be immersed 'in the life worlds and struggles of the oppressed', doing analysis, theological reflection and prophetic actions together. Such actions might be in the form of spontaneous, sporadic and disconnected irruptions. If such irruptions occur all the time, in settlements all over the city, and start to become networked in reflective and more sophisticated ways, they could indeed start to become a substantive movement of urban liberation from below.

A spatial justice agenda is about mending the oikos of God, now deeply fractured and scarred. It implies the whole oikos (household) of God - people, land, space and place, in their interconnectedness - being redeemed, reconciled and held in the life-giving womb of the earth God. It would start out as a transdisciplinary agenda, sharing knowledge and lived experiences between and among different academic disciplines, social and faith-based movements, and suffering people, clearly and collectively articulating spatial injustices and prophetic imaginaries in response.

It would become post-disciplinary action from below, dissolving colonial disciplinary constructs as it recognises the Spirit hovering over the Earth: seeking to arrest spirits and gods of spatial exclusion and oppression, in the interest of something radically new.

\section{Acknowledgements Competing interests}

The author declares that he has no financial or personal relationships that may have inappropriately influenced him in writing this article.

\section{Author's contributions}

I developed this article as part of a research focus in the Centre for Contextual Ministry that engages issues related to social justice and reconciliation. In September of 2015 we hosted a Consultation entitled Spatial Justice and Reconciliation and this article reflects the theological challenge that arose from this Consultation.

\section{References}

Amin, A., 2006, 'The good city', Urban Studies 43(5/6), 1009-1023. http://dx.doi org/10.1080/00420980600676717

Bergmann, S., 2007, 'Theology in its spatial turn: Space, place and the built environment, challenging and changing the images of God', Religion Compass 1(3), 353-379.

Brand, D., De Beer, S., De Villiers, I. \& Van Marle, K., 2013, 'Poverty as injustice', Law, Democracy and Development 17, 237-297. http://dx.doi.org/10.4314//dd. v17i1.13
Brueggemann, W., 1977, The land: Place as gift, promise and challenge in Biblical faith, Fortress Press, Minneapolis, MN.

Church Land Programme, n.d, About CLP, viewed 16 June 2016, from http://www. churchland.org.za

Conradie, E.M., 2006, Christianity and ecological theology: Resources for research, SUN Press, Stellenbosch.

Cornell, D., 2014, Law and revolution in South Africa: UBuntu, dignity, and the struggle for constitutional transformation, Fordham University Press, New York.

Cornell, D., Mamdani, M. \& Terreblanche, S., 2008, 'Only complete reform of economy can defuse tensions', Cape Times, 28 May, viewed 12 June 2016, from http:// abahlali.org/node/3606/

De Beer, S.F., 2014, “'Between life and death": On land, silence and liberation in the capital city', HTS Teologiese Studies/Theological Studies 70(1), Art. \#2075, 1-7. http://dx.doi.org/10.4102/hts.v70i1.2075

De Beer, S.F. \& Swart, I., 2014, 'Towards a fusion of horizons: Thematic contours for an urban public theological praxis-agenda in South Africa', HTS Teologiese Studies/ Theological Studies 70(3), Art. \#2812, 1-9. http://dx.doi.org/10.4102/hts.v70i3.2812

De Beer, S.F. \& Vally, R., 2015, Pathways out of homelessness. Research Report 2015, University of Pretoria, Pretoria.

Dennis Hurley Centre, 2012, The purpose of the DHC, viewed 16 June 2016, from http://www.dennishurleycentre.org

Department of Cooperative Governance and Traditional Affairs, 2014, Integrated Urban development framework, DCOGTA, Pretoria.

De Villiers, I., 2014, 'Tshwane 2055 and the (im)possibility of spatial justice', De Jure 47(2), 202-217.

ESSET, n.d, Programmes, viewed 16 June 2016, from http://www.esset.org.za/ content/programmes.html

Gibson, N., 2011, Fanonian practices in South Africa: From Steve Biko to Abahlal baseMjondolo, Palgrave Macmillan, New York.

Görgens, T. \& Van Donck, M., 2012, "Exploring the potential of the "right to the city" to integrate the vision and practice of civil society in the struggle for the sociospatial transformation of South African cities', paper presented at the conference Strategies to overcome poverty and inequality: Towards Carnegie III, 3rd-7th September, viewed 10 April 2014, from http://isandla.org.za/publications/161/

Gorringe, T., 2002, A theology of the built environment: Justice, empowerment, redemption, Cambridge University Press, Cambridge.

Harvey, D., 1978, 'The Urban programme under capitalism: A framework for analysis', International Journal of Urban and Regional Research 2(1-4), 101-131. http:// dx.doi.org/10.1111/j.1468-2427.1978.tb00738.x

Harvey, D., 2000, Spaces of hope, University of California Press, Berkeley, CA.

Harvey, D., 2012, Rebel cities: From the right to the city to the urban revolution, Verso, London.

Hendricks, F. \& Pithouse, R., 2013, 'Urban land questions in contemporary South Africa: The case of Cape Town', in F. Hendricks, L. Ntsebeza \& K. Hellner (eds), The promise of land. Undoing a century of dispossession in South Africa, pp. 103-129, Jacana Media (Pty)Ltd, Johannesburg.

Holtzhausen, H., 2015, 'Ubuntu and the quest for land reform in South Africa', Verbum et Ecclesia 36(2), Art. \#1431, 1-8. http://dx.doi.org/10.4102/ve.v36i2.1431

Inge, J., 2003, A Christian theology of place, Ashgate, Aldershot, UK.

Isandla Institute, n.d., What we do, viewed 16 May 2016, from http://isandla.org.za/ about/what-we-do/

Ivakhiv, A.I., 2001, Claiming sacred ground: Pilgrims and politics at Glastonbury and Sedona, Indiana University Press, Bloomington, IN.

Joseph, R., 2014, 'The gentrification of Woodstock: From rundown suburb to hipster heaven', The Guardian, 12 August, viewed 13 June 2016, from https://www. theguardian.com/cities/2014/aug/12/gentrification-woodstock-cape-townsuburb-hipster-heaven

Kjellberg, S., 2000, Urban ecotheology, International Books, Utrecht.

Koopman, N., 2014, 'Inclusive dignity and land reform in South Africa', Scriptura 113, 1-8. http://dx.doi.org/10/7833/113-0-917

Kotze, N., 2013, 'A community in trouble? The impact of gentrification on the Bo-Kaap', Urban Izziv 24(2), 124-132.

Lefebvre, H., 1974, The production of space, Anthropos, Paris.

Lefebvre, H., 1996, Writings on cities, transl. and introduced E. Kotman \& E. Labas, Blackwell, Oxford.

Madulammoho Housing Association, 2010, Welcome to Madulammoho!, viewed 14 June 2016, from http://www.mh.org.za

Mandela, N., 1995, 'Message by President Nelson Mandela on National Reconciliation Day', posted 16 December, viewed 27 May 2016, from http://www.anc.org.za/ show. .php?id=3646

Mashau, T.D. \& Kritzinger, J.N.J., 2014, Pavement encounters for justice: Doing transformative missiology with homeless people in the City of South Africa, AcadSA CC, Parow.

McKenzie, E, 1994, Privatopia: Homeowner associations and the rise of residential private government, Yale University Press, New Haven, CT.

Meiring, J., 2014, 'Theology in the Flesh. Exploring the corporeal turn from a southern African perspective', PhD dissertation, VU University, Amsterdam.

Meiring, J, in press, 'How does justice smell? Reflections on space and place, justice and the body', HTS Theological Studies. 
Meiring, J. \& Müller, J.C., 2010, 'Deconstructing the body: Body theology, embodied pastoral anthropology and body mapping', Verbum et Ecclesia 31(1), Art. \#367, pastoral.

Merrifield, A. \& Swyngedouw, M. (eds.), 1995, The urbanization of injustice, Lawrence \& Wishart, London.

Moltmann, J., 1985, God in creation: An ecological doctrine of creation, SCM, London.

Moltmann, J, 2002, 'Gott und Raum', in J. Moltmann \& C. Rivuzumwami (eds.), Wo its Gott? Gottesräume - Lebensräume, pp. 29-41, Neukirchen-Vluyn, Neukirchen.

National Planning Commission, 2012, National Development Plan 2030. Our futureMake it work, The Presidency, Republic of South Africa, Pretoria.

Norberg-Schulz, C, 1980, Genius Loci. Towards a phenomenology of architecture, Rizzoli, New York.

Perkinson, J., 2001, 'Theology and the city: Learning to cry, struggling to see', Cross Currents 51(1), 95-114.

Primavesi, A., 2000, Sacred Gaia: Holistic theology and earth system science, Routledge, London.

Prinsloo, G.T.M., 2005, 'The role of space in the Shire Hama'lot (Psalms 120-134)', Biblia 86, 457-477.

Prinsloo, G.T.M., 2013, 'Suffering bodies - Divine absence: Towards a spatial reading of ancient near eastern laments with reference to Psalm 13 and an Assyrian Elegy (K890)', OTE 26(3), 773-803.

Prinsloo, G.T.M., 2015, 'Suffering as separation: Towards a spatial reading of Psalm 11' Old Testament Essays (New Series) 28(3), 777-806. http://dx.doi.org/10.17159/ 2312-3621/2015/v28n3a13

Prinsloo, G.T.M. \& Maier, C.M., 2014, Constructions of space V. Place, space and identity in the ancient Mediterranean world, Bloomsbury T\&T Clark, London.

Punt, J., 2005, 'Paul, body theology, and morality: Parameters for a discussion', Neotestamentica 39(2), 359-388.

Resane, K.T., 2015, 'Naboth's vineyard: Theological lessons for the South African land issue', Acta Theologica 35(1), 174-188.
Restitution Foundation, 2016, Why restitution?, viewed 13 June 2016, from http:// www.restitution.org.za

Soja, E., 2010, Seeking spatial justice, University of Minnesota Press, Minneapolis, MN.

South African History Online (SAHO), 2015, The Natives' Land Act of 1913, viewed 29 May 2016, from http://www.sahistory.org.za/topic/natives-land-act-1913

Street People's Forum, 2016, About, viewed 25 May 2016, from http:// streetpeoplesforum.org.za/wp/

Terreblanche, S., 2012, 'Rich get richer through unfettered capitalism, not own devices', Mail and Guardian, 3 August, viewed 14 June 2016, from http://mg. co.za/article/2012-08-03-00-rich-get-richer-through-unfettered-capitalism-notown-devices

Tinker, G.E., 1994, 'The full circle of liberation: An American Indian theology of place', in D.G. Hallmann (ed.), Ecotheology: Voices from South and North, pp. 218-224, WCC, Geneva.

Tshwane Leadership Foundation, 2016, Our vision, viewed 25 May 2016, from http:// tlf.org.za/about-us/

University of Pretoria, 2015, Pathways out of homelessness in the City of Tshwane Research and Strategy Development for the Homeless Summit 2015, viewed 25 May 2016, from http://www.up.ac.za/media/shared/187/ZP_Files/ccm-newspage-events-download_july-2015.zp63001.pdf

Van Marle, K. \& De Villiers, I., 2013, 'Law and resistance in the city of Pretoria: Space, history and the everyday', The Australian Feminist Law Journal 38, 129-145.

Van Schalkwyk, A., 2014, 'Space, place and ecology: Doing ecofeminist urban theology in Gauteng', HTS Teologiese Studies/Theological Studies 70(3), Art. \#2767, 1-13. $\mathrm{http}: / / \mathrm{dx}$.doi.org/10.4102/hts.v70i3.2767

Vellem, V., 2014, 'Life-giving assets at a Johannesburg informal settlement: Black faith and the false gods of multi-culturalism in the twenty-first century', in R.D. Smith, W. Ackah \& A.G. Reddie (eds.), Churches, blackness, and contested multiculturalism: Europe, Africa, and North America, pp. 207-212, Palgrave MacMillan, New York.

Warehouse, n.d., What we do?, viewed 8 June 2016, from http://www.warehouse.org.za Yeast City Housing, n.d., About us, viewed 8 June 2016, from http://www.ych.org.za 